\title{
Science Education at the Polytechnic University of Baja California, México
}

\author{
Maria Amparo Oliveros Ruiz ${ }^{{ }^{*}}$, Benjamín Valdez Salas ${ }^{2}$, Michael Schorr Wienner ${ }^{2}$, \\ Lidia Vargas Osuna ${ }^{1}$, Eduardo Cabrera Cordova ${ }^{1}$, Ulises Castro Peñaloza ${ }^{1}$ \\ ${ }^{1}$ Polytechnic University of Baja California, Mexicali, Mexico \\ ${ }^{2}$ Institute of Engineering, University of Baja California, Mexicali, Mexico \\ Email: maoliverosr@upbc.edu.mx
}

Received August $3^{\text {rd }}$, 2012; revised September $5^{\text {th }}, 2012$; accepted September $18^{\text {th }}, 2012$

\begin{abstract}
The educational model that is currently being implemented with the Polytechnic University of Baja California (UPBC) students of Engineering in Manufacturing Technology is presented in this paper. This model gives us the pattern of how to deal with the problem of teaching the nature of science and technology with quality, in particular, questions about how science and technology validate their knowledge and how it works in today's world. The nature of science includes aspects of epistemology and sociology, and the relationships with science, technology and society (STS): complex and innovative contents in science education (Acevedo, 2000). Also shown is the result of applying the Opinions Questionnaire on Science, Technology and Society (OQSTS), which allows an assessment of the views and attitudes of students on STS issues. Understanding these concepts: Science, Technology and Society is considered by specialists as a central axis of scientific alphabetization for all and as such, should be incorporated into the curricula of higher education and especially in Engineering as it enables awareness and changing attitudes of the student to confront ethical and moral dilemmas.
\end{abstract}

Keywords: Science Teaching; STS Humanistic Education; Attitudinal Change

\section{Introduction}

The Polytechnic Universities of México were created in 2001 and were designed to offer engineering degrees and postgraduate studies at the level of expertise. Actually, there are 35 Polytechnic Universities in México. The academic programs at these universities have three distinctive features: Teaching, Applied Research and Linkage.

The UPBC is a public institution of the state government; it started operation in May 2006 with the objective of preparing professionals with a solid technical background and values, aware of the national economic, social and cultural context. Currently it has an enrollment of 800 students and 130 teachers.

The university offers four engineering degrees: Energy, Information Technology, Mechatronics and Manufacturing Technology.

\section{What Is the Nature of Science?}

The nature of science is a meta-knowledge about the emerging science of interdisciplinary reflections made from history, philosophy and sociology. Including the reflection on methods to validate the scientific knowledge, the values involved in science activities, relations with technology and its contributions to culture and progress of society; it is also known as philosophy of science.

\section{Movement Science, Technology and Society (STS)}

On the other hand, the STS movement regards science and technology as essential core human activities, its importance lies in the mutual interactions between science, technology and society (Acevedo, Vazquez, \& Manassero, 2003)

As a didactic approach for teaching science and technology; STS is characterized by highlighting these mutual relations: its central idea that acts as a guideline for the objectives, contents, methodology and assessment of this approach. A predominant instrument for the evaluation of STS is "Views on ScienceTechnology-Society-VOSTS” (Aikenhead \& Ryan, 1992) that is adapted to Castilian as COCTS (Cuestionario de opinions en Ciencia, Tecnologia y Sociedad) (Vazquez \& Manasero, 1999).

\section{The Need for New Approaches in Teaching Science}

Research in science teaching has identified several difficulties in the process of learning science identified as classics: they are the structure of the conceptual contents, formal requirement level and the influence of prior knowledge and preconceptions of the student. In recent years a certain shift is detected in the centers of research interest and is paying increasing attention to factors such as students' epistemological conceptions and reasoning strategies or metacognition (Campanario, 1999).

For this research we use the strategy called "conceptual change as a starting point of constructivist ideas” (Driver, 1988) which recommends the following four strategies for constructivist learning:

- The students' ideas should be part of the explicit discussion in the classroom;

- The status of the ideas should be discussed and negotiated with students;

- The justification of the ideas should be an explicit component of the curricula; 
- The debate in the classroom should be aware that metacognition plays a central role in conceptual change.

The concept of metacognition involves the interrelationship between knowledge, awareness and control of the learning process, shown graphically in Figure 1.

\section{Experimental Details}

This study uses a quantitative method; the measurement tool was applied to students of the UPBC. For this pilot study the full questionnaire: Opinions Questionnaire on Science, Technology and Society (OQSTS), which allows an assessment of the views and attitudes of students on STS issues, was utilized. But for the purposes of this research, the results of only six questions will be shown. This questionnaire allows respondents to express their own point of view on a wide range of STS topics. The tool COCTS was designed by (Vazquez \& Manassero, 1999) and employs a Likert psychometric scale for questionnaires and investigations related to social sciences. Nine options were applied, but in a later analysis it is summarized into five options. After applying the questionnaires, the answers were read automatically using a Cannon DR-3080C scanner with the support of Remark Office OMR 5.5 package, which led directly to record survey data in an SPSS (Statistical Package for the Social Sciences) for statistical processing.

It is a multiple choice model (MCM) where the person who responds to the matter raised in each issue evaluates on a nine-point scale, their degree of agreement or disagreement with each of the sentences given. All have the same format, beginning with a header from a few lines where there is a problem for which you want to know the attitude of the respondent, followed by a list of situations that offers a range of different explanations on the issue raised and finally, an option not to answer as "I don't understand the question". Although the methodology is quantitative it allows a qualitative analysis too.

The questionnaire was applied to 60 students in their basic stage that comprises from the first to the third semester, and 60 students from terminal stage (sixth to eighth semester), representing a population of 120 students. The instrument will allow us to detect the true extent of knowledge that students in different degrees have of the STS concepts according to the expert panel of judges on STS issues (Elfin, Stuart, \& Reisch, 1999).

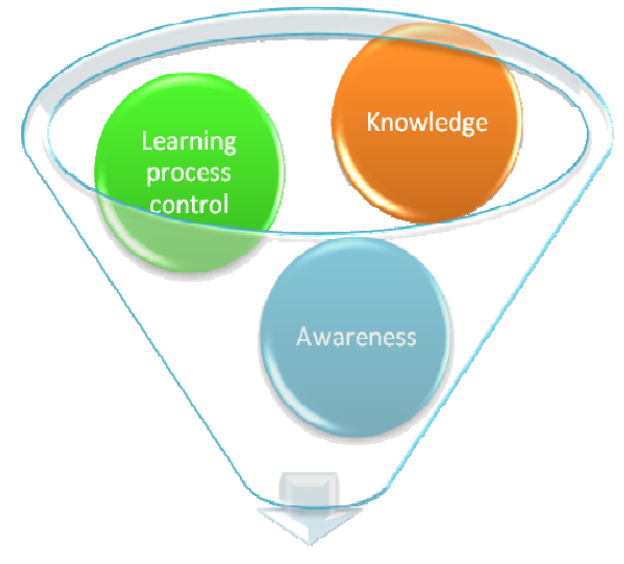

Metacognition

Figure 1.

Graphic representation of the concept of Metacognition.

\section{Results and Discussion}

\section{Attitudes toward Interactions between Science, Technology and Society}

The analysis of the results is divided in two ways, the influence of society on science and technology and their influence on society.

On the influence of society towards science and technology, it is considered that most students recognized that society influences science and technology, especially when is raised in a general way. However, when it carries out to diverse contexts such as government, industrial companies, the army or the science and technology education, students show different opinions

$10 \%$ believe the government should not invest money in research, $80 \%$ say that control of the research should be on businesses. 95\% recognized the influence of politics, but does not accept government control over science to seek greater efficiency. $98 \%$ suspect that science and government make decisions without caring the opinions of others

We can see that the general attitude of students is more favorable to the influence of society on science, in relation to questions about their knowledge of influence of history, epistemology and sociology. Regarding to science and technology responses is mostly inadequate (Figure 2).

\section{Influence of Science and Technology on Society}

Students also recognize that science and technology influence society even though science is perceived with less intensity than the technology.

$85 \%$ of students find scientists responsible for any damages that may occur as a product of their investigations. $60 \%$ agreed on the ability of science and technology to help solve main social problems affecting the world: poverty, crime, unemployment.

Data show that most students did not express confidence in solving everyday problems, as well as $40 \%$ of students pronounce in doubt on the role of science and technology, to benefit the quality of life of society (Figure 3).

\section{Influence of Society on Science and} Technology

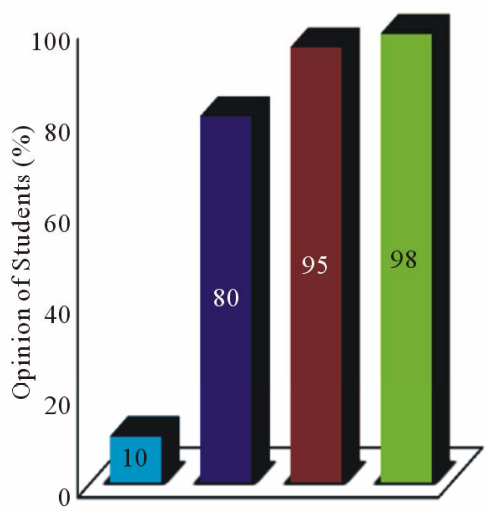

Government should not invest in research

Companies must control research

- Government control over science is not accepted

It is suspected that soience and government do not care about others opinion

Figure 2.

Influence of society on science and technology. 
Influence of Science and Technology on Society

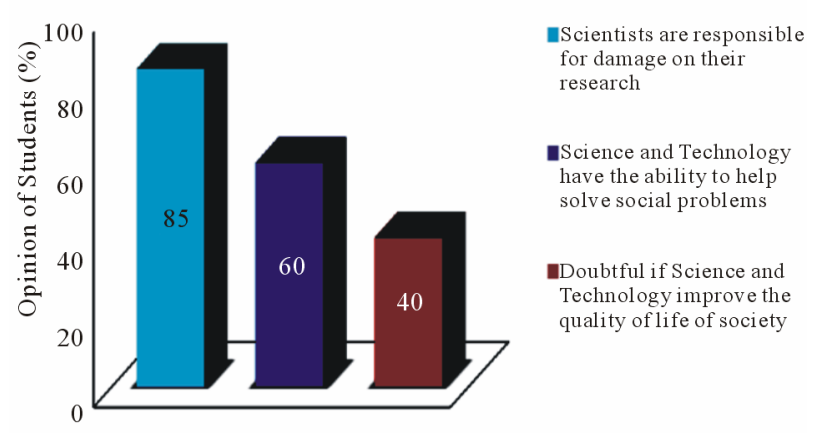

Figure 3.

Influence of science and technology on society.

It was also observed that the surveyed students have not received an education in specific or general STS concepts to enable them to understand such relationship, nor to understand the nature of science in particular, because the university curricula and below grades did not consider it enough. Therefore, their beliefs and attitudes are not configured for a formal school curriculum to address these issues directly and explicitly. Consequently, education rests on a hidden school curriculum, implicit and unplanned with teacher beliefs implicitly transmitted in different classroom activities and laboratory, textbooks and other curricula materials, and especially informal education: information media, social programs, magazines, movies, museums and exhibitions of science and technology (Garritz, Porro, Rembado, \& Trinidad, 2007).

\section{Conclusion}

The purpose of science teaching with STS focus, in addition to preparing UPBC students to become professionals with scientific knowledge, also helps them understand better how science and technology works in the world today.

Given the axiological nature impregnated with attitudinal contents and values of education, STS is seeks the adherence of the students towards a particular position. It presents different perspectives, encouraging the students to invest greater efforts to acquire the knowledge's and the tools for their integration in the modern society, so they can play a predominant position for the public and personal benefit. In this mode they will reach a better understanding to evaluate critically the actual interactions between academic, industry and government. This knowledge will facilitate the understanding of the global world in which the students will improve their professional development (Aikenhead, 2002).

It is useful for teachers to have a formation in STS concepts in order to achieve scientific and technological alphabetization of the citizenry. Programs are also required to address directly and explicitly the STS contents and to allow an effective reflection of teaching staff on these issues. (Aikenhead \& Rayan, 1992). Therefore, we must always include a plurality of authors or approaches with a depth and extension consistent with the abilities and developmental level of students.

\section{REFERENCES}

Acevedo, J. A. (2000). Algunas creencias sobre el conocimiento científico de los profesores de Educación Secundaria en Formación. Bordón, 52, 5-16.

Acevedo, J. A., Vazquez, A., \& Manassero, M. A. (2003). Papel de la educación CTS en una alfabetización científica y tecnológica para todas las personas. Revista Electrónica de Enseñanza de las Ciencias, 2, 80-112.

Aikenhead, G. S., \& Ryan, A. G. (1992). The development of a new instrument: "Views on science-technology-society" (VOSTS). Science Education, 76, 477-491. doi:10.1002/sce.3730760503

Aikenhead, G. S. (2002). STS Education: Crusader for science education: Celebrating and critiquing the vision of Peter J. Fensham. New York: Routledge Press.

Campanario, J. M. (1999). Consolidation for the scientist. Social Studies of Science, 23, 342-362. doi:10.1177/030631293023002005

Driver, R. (1998). A constructivist approach to curriculum development in science. Science Education, 6, 109-120.

Elfin, J., Stuart, G., \& George, R. (1999). The Nature of Science: A perspective from the philosophy of science. Journal of Research in Science Teaching, 36, 107-116. doi:10.1002/(SICI)1098-2736(199901)36:1<107::AID-TEA7>3.0.C $\underline{\mathrm{O} ; 2-3}$

Garritz, A., Porro, S., Rembado, F. M., \& Trinidad, R. (2007). LatinAmerican teachers pedagogical content knowledge of the particulate nature matter. Journal of Science Education, 8, 79-84.

Manassero, M. A., \& Vázquez, A. (1999). Actitudes hacia la influencia de la sociedad en la ciencia y la tecnología. Arbor, 637, 45-72.

Vázquez, A., \& Manasero, M. A. (1999). New response and scoring models for the "views on science, technology-society" instrument (VOSTS). International Journal of Science Education, 21, 231-242. 